\title{
SCHOLARLY PUBLICATIONS OF THE MAHARAJA SAIYAJIRAO UNIVERSITY OF BARODA, VADODARA : A BIBLIOMETRICS STUDY
}

\author{
Dr. Priyanki Vyas \\ \& \\ Mrs. Roma Asnani
}

\begin{abstract}
Many evaluation studies have been carried out with the help of bibliometrics study to know the growth of research papers at national and international level, scientific productivity of authors and institutions, most relevant journals and their impact factor, citation analysis etc. This paper aimed to analysis of 2200 publications of with 23268 citations Maharaja Saiyajirao University of Baroda by using three indices, which hosted on Web of Knowledge platform i.e. Science Citation Index, Social Science Citation Index and Arts and Humanities Citation Index along with citations during the period of 2009 to 2018. Bibliometrix R tool used for summarizing results of Web of Science Data and VOSviewer used to demonstrate country's collaborationmapping analysis.
\end{abstract}

\section{Introduction}

The Maharaja Sayajirao University of Baroda (1949) has blossomed from the Baroda College (1881) which is one of the oldest centres of learning in western India. It comprises 14 Faculties, having 90 Departments, 3 constituent colleges with 1200 well-qualified faculty members and 1500 administrative staff to facilitate the learning of more than 35,000 students having cosmopolitan life on campus and several specialized centres and institutes offering wide spectrum of courses from kindergarten to Ph.D. also with an excellent exposure to the co curricular and extracurricular experiences ${ }^{1}$.

This article presents a study of detailed analysis of the research output of M S University of Baroda published during 2009-2018. An attempt has been made to analyse average citations per papers, $\mathrm{H}$ index, most prominent research areas, academician's contribution in most popular journals, international collaboration and highly cited papers.

\section{Literature Review}

There are many statistical methods to analyse research publications through Bibliometrics: Sangwal, 2011) examined the growth of articles from selected randomly three databases out of 20 different databases in humanities social sciences and science \& technology covered the period 1968-1987. In addition, author also analysed data of growth of journals, papers and authors in malaria research with publication year of journals for the period 1955-2005 and compared with the predictions of the power-law equation ${ }^{2}$. (Abolghassemi Fakhree \& Jouyban, 2011) made comparative study analysis among major Iranian Medical University by using Scopus to know their research performance. From this study founded that Tehran, Shiraz and Shahid Beheshti were top leading Universities on the base of high publication, number of citations and total $\mathrm{H}$ indices. Authors also analyzed top ten authors and top journals. Authors also concluded that Tahran University of medical Sciences performance was on top as compared with other leading medical Universities in the world and being a low research budget nation Iran performing well. Authors also suggested research collaboration to increase research 
activities $^{3}$. (Knievel \& Kellsey, 2005) analysed and compared citations to articles published in various journals in eight humanities fields. Authors extracted 9,131 citations from journals, which published in 2002 and found that citation patterns varied widely among humanities disciplines. Authors founded that French and German language more dominant as compared to others while in some fields' citation to monographs seen less than the expected numbers ${ }^{4}$.

\section{Objectives:}

Objectives of this study are:

- To measure average citation and $\mathrm{H}$ index of publications,

- To identify most prominent 25 research areas,

- To identify University Academician's Contribution in top 10 journals,

- To explore the International collaboration

- To explore top 10 highly cited papers

\section{Methodology:}

The publications of MSU retrived from selected three indices hosted on Web of Knowledge platform i.e. Science Citation Index, Social Science Citation Index and Arts and Humanities Citation Index. Boolen Operators was used in advance search engine to retrieve the data. A total number of 2200 publications indexed in the mentioned database, published by M S University of Baroda during the period of 2009-2018. The data collected on $19^{\text {th }}$ July 2019. The published materials such as article (1935), Book Chapter (2), proceedings paper(58), Retracted Publication (1), biographical-item (2), book review (4), Correction (4), editorial material (19), letter (18), meeting abstract (69), review (86), book chapter (2) considered as research publications for this study only. The "Bibliometrix", R package used to perform various quantitative analyses on the extracted bibtex format file of Web of Science for publications and citations data. VOSviewer used to demonstrate country's collaboration-mapping analysis.

\section{Results and discussion}

\section{Publications and Citations}

A total number of 2,200 publications of M S University of Baroda indexed in Web of Science during the period of 2009- 2018. overall publications had received 23,268 citations including self-citations. The average citation per publication was 10.58. The $\mathrm{H}$ index of overall publications was 53. It could be observed in results that the publications in 2010 were having highest average with 17.46 citations per publication followed by 2009 with 16.04 citations.

\begin{tabular}{|c|r|r|r|r|r|}
\hline & \multicolumn{1}{|c|}{$\begin{array}{c}\text { Total } \\
\text { Year }\end{array}$} & $\begin{array}{c}\text { Average } \\
\text { Citations } \\
\text { Per } \\
\text { Publications }\end{array}$ & H index & $\begin{array}{c}\text { Sum of } \\
\text { Times } \\
\text { Cited }\end{array}$ & $\begin{array}{c}\text { Without } \\
\text { Self } \\
\text { citations }\end{array}$ \\
\hline 2009 & 207 & 32 & 16.04 & 3,320 & 3,312 \\
\hline 2010 & 188 & 31 & 17.46 & 3,282 & 3,264 \\
\hline 2011 & 203 & 28 & 15.61 & 3,169 & 3,149 \\
\hline 2012 & 233 & 30 & 13.64 & 3,177 & 3,141 \\
\hline 2013 & 242 & 26 & 12.76 & 3,087 & 3,056 \\
\hline 2014 & 241 & 24 & 12.05 & 2,903 & 2,871 \\
\hline 2015 & 236 & 20 & 7.47 & 1,762 & 1,721 \\
\hline
\end{tabular}


Towards Excellence: An Indexed, Refereed \& Peer Reviewed Journal of Higher Education / Dr. Priyanki Vyas \& Mrs. Roma Asnani/ Page 202-208

\begin{tabular}{|c|r|r|r|r|r|}
\hline 2016 & 214 & 16 & 5.82 & 1,245 & 1,236 \\
\hline 2017 & 205 & 14 & 4.15 & 851 & 835 \\
\hline 2018 & 231 & 9 & 2.04 & 472 & 434 \\
\hline Total & $\mathbf{2 2 0 0}$ & $\mathbf{5 3}$ & $\mathbf{1 0 . 5 8}$ & $\mathbf{2 3 , 2 6 8}$ & $\mathbf{2 0 , 5 5 4}$ \\
\hline
\end{tabular}

\section{University Contribution in most prominent 25 Research Areas}

University has contributed in various research areas, In this study, We have extracted most prominent 25 reaseach areas from Web of Science platform, where University has conducted research work in mention below subject areas. It could be observed that University academicians have highest publications published in the subject of Chemistry and least publications published in the subject of Food Science Technology as per mentioned below results of 25 research areas.

\begin{tabular}{|l|r|}
\hline Research Areas & No. of Articles \\
\hline Chemistry & 609 \\
\hline Pharmacology Pharmacy & 306 \\
\hline Physics & 292 \\
\hline Materials Science & 218 \\
\hline Engineering & 199 \\
\hline Biochemistry Molecular & \\
Biology & 151 \\
\hline Science Technology & 115 \\
Other Topics & 87 \\
\hline Geology & \\
\hline Biotechnology Applied & 84 \\
Microbiology & 74 \\
\hline Crystallography & \\
\hline Environmental Sciences & 70 \\
Ecology & 65 \\
\hline Plant Sciences & 61 \\
\hline Polymer Science & 53 \\
\hline Microbiology & 46 \\
\hline Optics & 42 \\
\hline Neurosciences Neurology & 41 \\
\hline Cell Biology & 40 \\
\hline Energy Fuels & 38 \\
\hline Nuclear Science & 36 \\
\hline Technology & 34 \\
\hline Mathematics & 32 \\
\hline Agriculture & 29 \\
\hline Toxicology & 28 \\
\hline Water Resources & 27 \\
\hline Endocrinology & \\
Metabolism & \\
\hline Food Science Technology & \\
\hline & \\
\hline & \\
\hline
\end{tabular}

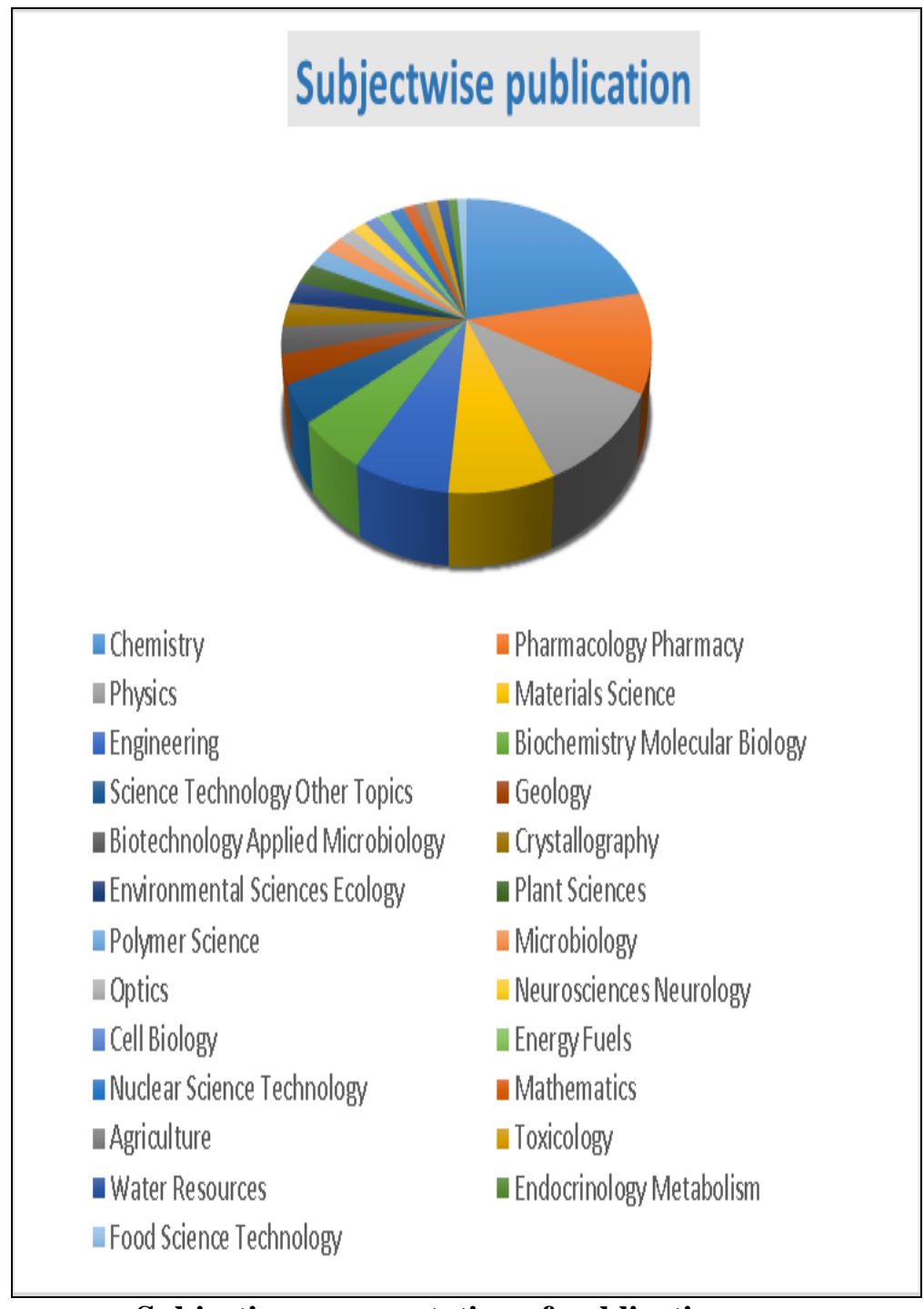

Subjective representation of publications

\section{University Academician's Contribution in top 10 Journals}


University academicians have published their various research papers in journals related with their research areas, In this study, We have extracted top 10 journals during the period of 2009-2018 from Web of Science platform. It could be observed that University academicians have highest publications published in the Physical Review C Journal and least publications published in the Synthetic Communications Journal. Journals' H index, $\mathrm{G}$ index and $\mathrm{M}$ index extracted from the Bibliometrix: $\mathrm{R}$ package. Where, $\mathrm{H}$ index intends to express the journal's number of articles (h) that have received atleast (h) citations; $G$ index intends to quantify productivity in science based on their publication record; and M-Index is the H-index divided by the number of years that Journals have been published. It could be obseved that Physical Review $\mathrm{C}$ Journal has highest citations, $\mathrm{H}$ index, $\mathrm{G}$ index and $\mathrm{M}$ index as compared to other journals in mentioned below results.

\begin{tabular}{|l|r|r|r|r|r|}
\hline Journals & $\begin{array}{l}\text { No. of } \\
\text { Articles }\end{array}$ & \multicolumn{1}{l|}{$\begin{array}{l}\text { Time } \\
\text { cited }\end{array}$} & \multicolumn{1}{l|}{ H-Index } & \multicolumn{1}{l|}{ G-Index } & \multicolumn{1}{l|}{ M-Index } \\
\hline Physical Review C & 41 & 556 & 14 & 22 & 1.2727273 \\
\hline RSC Advances & 40 & 454 & 11 & 19 & 1.375 \\
\hline Current Science & 27 & 130 & 7 & 10 & 0.6363636 \\
\hline $\begin{array}{l}\text { Molecular Crystals And } \\
\text { Liquid Crystals }\end{array}$ & 25 & 194 & 8 & 13 & 0.7272727 \\
\hline $\begin{array}{l}\text { Journal Of The Geological } \\
\text { Society Of India }\end{array}$ & 24 & 142 & 7 & 10 & 0.6363636 \\
\hline Plos One & 23 & 237 & 9 & 14 & 0.8181818 \\
\hline Aaps Pharmscitech & 22 & 372 & 10 & 19 & 0.9090909 \\
\hline Polyhedron & 21 & 283 & 10 & 16 & 0.9090909 \\
\hline Tetrahedron Letters & 16 & 143 & 7 & 11 & 0.7 \\
\hline Synthetic Communications & 15 & 65 & 4 & 7 & 0.3636364 \\
\hline
\end{tabular}

\section{International Collaboration}

International collaboration based on publications which reveals that university academicians published their publications in association with other countries. We have extracted 10 countries along with number of publications from Web of Science. It could be obsevered that higest publications of Maharaja Sayajirao University of Baroda associated with USA as compared to other countries. VoSViewer used to demonstrate country's collaboration-mapping network. This network intends to show how many countries associated together for publications.

\begin{tabular}{|l|r|}
\hline Countries & Publications \\
\hline USA & 113 \\
\hline Germany & 35 \\
\hline England & 26 \\
\hline $\begin{array}{l}\text { Peoples R } \\
\text { China }\end{array}$ & 26 \\
\hline Spain & 25 \\
\hline South & 24 \\
Korea & 23 \\
\hline Brazil & 21 \\
\hline France & 17 \\
\hline Canada & \\
\hline
\end{tabular}




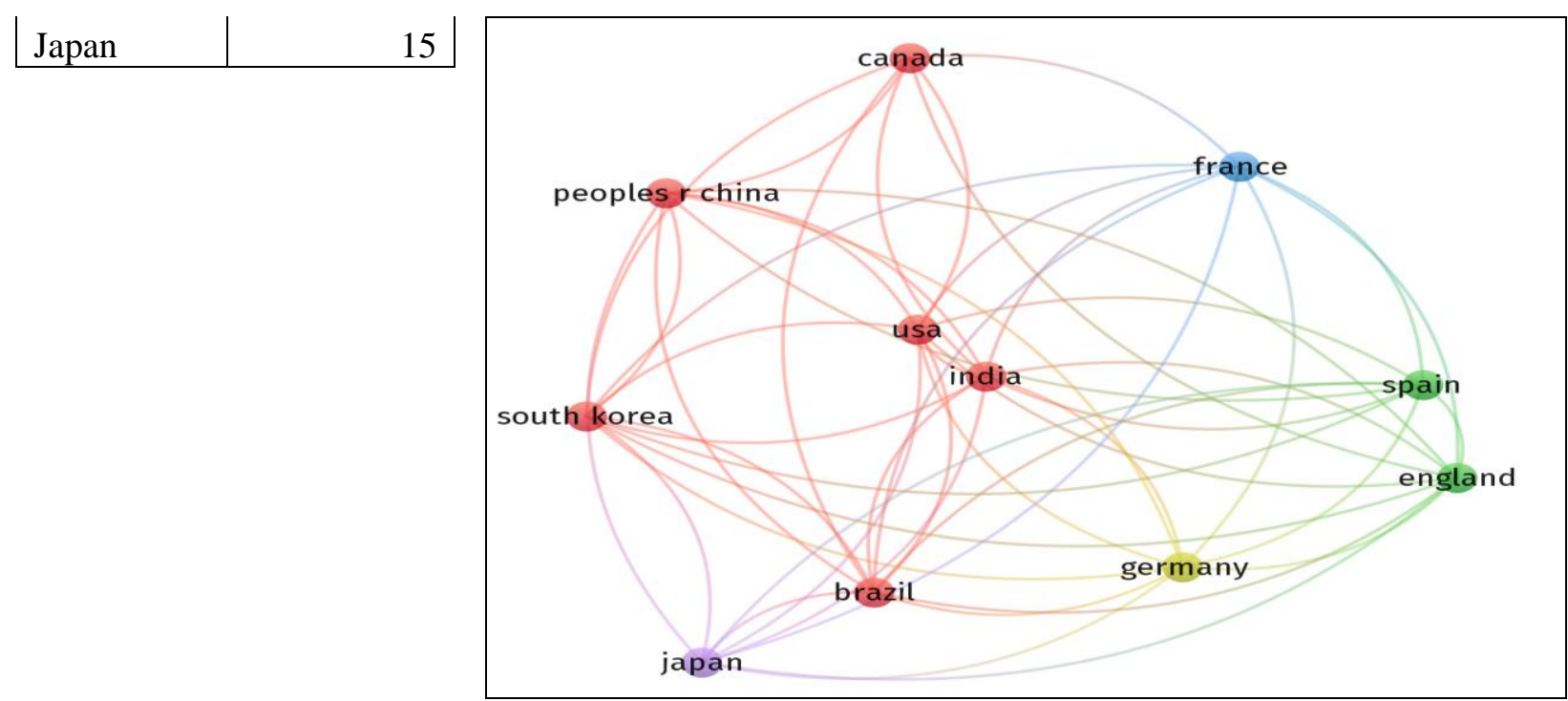

\section{Top Ten Highly Cited Papers}

\begin{tabular}{|c|c|c|}
\hline $\begin{array}{l}\text { SI. } \\
\text { No. }\end{array}$ & Titles & $\begin{array}{l}\text { Times } \\
\text { Cited }\end{array}$ \\
\hline 1 & $\begin{array}{l}\text { Upadhyay, Kamal K.; Bhatt, Anant N.; Mishra, Anil K.; et al. (2010). The intracellular drug } \\
\text { delivery and anti tumor activity of doxorubicin loaded poly(gamma-benzyl L-glutamate)-b- } \\
\text { hyaluronan polymersomes. Biomaterials,31 (10), 2882-2892 }\end{array}$ & 235 \\
\hline 2 & $\begin{array}{l}\text { Upadhyay, Kamal K.; Bhatt, Anant N.; Mishra, Anil K.; et al. (2014). PEG - A versatile } \\
\text { conjugating ligand for drugs and drug delivery systems, Journal of Controlled Release, 192, } \\
67-81\end{array}$ & 231 \\
\hline 3 & $\begin{array}{l}\text { Yewale, Chetan; Baradia, Dipesh; Vhora, Imran; et al. (2013). Epidermal growth factor } \\
\text { receptor targeting in cancer: A review of trends and strategies. Biomaterials, } 34 \text { (34), 8690- } \\
8707\end{array}$ & 191 \\
\hline 4 & $\begin{array}{l}\text { Valodkar, Mayur; Modi, Shefaly; Pal, Angshuman; et al. (2011). Synthesis and anti-bacterial } \\
\text { activity of } \mathrm{Cu}, \mathrm{Ag} \text { and } \mathrm{Cu}-\mathrm{Ag} \text { alloy nanoparticles: A green approach. Materials Research } \\
\text { Bulletin, 46(3), 384-389 }\end{array}$ & 162 \\
\hline 5 & $\begin{array}{l}\text { Upadhyay, K. Kumar; Le Meins, J. -F.; Misra, A.; et al. (2009). Biomimetic Doxorubicin } \\
\text { Loaded Polymersomes from Hyaluronan-block-Poly (gamma-benzyl glutamate) Copolymers. } \\
\text { Biomacromolecules, } 10 \text { ( 10), 2802-2808 }\end{array}$ & 149 \\
\hline 6 & $\begin{array}{l}\text { Pal, Angshuman; Shah, Sunil; Devi, Surekha (2009). Microwave-assisted synthesis of silver } \\
\text { nanoparticles using ethanol as a reducing agent. Materials Chemistry and Physics, } 114 \text { (2-3), } \\
\text { 530-532 }\end{array}$ & 142 \\
\hline 7 & $\begin{array}{l}\text { Seju, U.; Kumar, A.; Sawant, K. K. (2011). Development and evaluation of olanzapine-loaded } \\
\text { PLGA nanoparticles for nose-to-brain delivery: In vitro and in vivo studies. } \\
\text { Acta Biomaterialia, } 7 \text { ( 12), 4169-4176 }\end{array}$ & 135 \\
\hline 8 & $\begin{array}{l}\text { Chandra, Sourov; Patra, Prasun; Pathan, Shaheen H.; et al. (2013). Luminescent S-doped } \\
\text { carbon dots: an emergent architecture for multimodal applications. Journal of Materials } \\
\text { Chemistry B, 1(18), 2375-2382 }\end{array}$ & 130 \\
\hline 9 & $\begin{array}{l}\text { Tripathi, Avinash C.; Gupta, Shiv Ji; Fatima, Gul Naz; et al. (2014). 4-Thiazolidinones: The } \\
\text { advances continue. European Journal Of Medicinal Chemistry, 72, 52-77 }\end{array}$ & 127 \\
\hline
\end{tabular}




\begin{tabular}{|c|c|c|}
\hline 10 & $\begin{array}{l}\text { Manjappa, Arehalli S.; Chaudhari, Kiran R.; Venkataraju, Makam P.; et al. (2011). Antibody } \\
\text { derivatization and conjugation strategies: Application in preparation of stealth } \\
\text { immunoliposome to target chemotherapeutics to tumor. Journal of Controlled Release, 150(1), } \\
2-22\end{array}$ & 121 \\
\hline
\end{tabular}

\section{Conclusions}

As mentioned above, the presented study explored the various bibliometrics parameters of publications of M S University of Baroda published during 2009-2018, which indexed in Web of Science Core Collection. 2200 publications indexed which were having a total number of 23,268 citations. The average citation per publication was 10.58. A total number of 609 research papers published in Chemistry research area. 41 publications of University have published in the Physical Review C Journal and that journal 556 times cited, its $\mathrm{h}$ index is 14 and $g$ index is 22 and $m$ index is 1.2727273 . USA country associated with Maharaja Sayajirao University of Baroda published highest publication during the research period. Top ten highly paper cited also examined. 


\section{$\underline{\text { References }}$}

1. http://www.msubaroda.ac.in/ accessed on 19th July 2017

2. Sangwal, K. (2011). Progressive nucleation mechanism and its application to the growth of journals, articles and authors in scientific fields. Journal of Informetrics, 5(4), 529-536. https://doi.org/10.1016/j.joi.2011.04.005

3. Abolghassemi Fakhree, M. A., \& Jouyban, A. (2011). Scientometric analysis of the major Iranian medical universities. Scientometrics, 87(1), 205-220. https://doi.org/10.1007/s11192-010-0336-z

4. Knievel, J. E., \& Kellsey, C. (2005). Citation Analysis for Collection Development: A Comparative Study of Eight Humanities Fields. The Library Quarterly, 75(2), 142168. https://doi.org/10.1086/431331

5. https://www.webofknowledge.com/ accessed on $19^{\text {th }}$ July 2017

\section{Dr. Priyanki Vyas \\ Associate Professor \\ Dept of Library \& Information Science \\ Dr. Babasaheb Ambedkar Open University, Ahmedabad}

\&

Mrs. Roma Asnani
Research Scholar 